\title{
Odnos zagrebačke gradske vlasti prema južnoj periferiji između dva svjetska rata*
}

\author{
HRVOJE ČAPO \\ Hrvatski institut za povijest \\ Zagreb, Hrvatska \\ hrvoje.capo@gmail.com
}

\begin{abstract}
Snažno useljavanje iz ruralnih krajeva nakon Prvoga svjetskog rata te kronični nedostatak stanova uzrokovali su naseljavanje južne periferije Zagreba. Taj je prostor zbog smještaja između željezničke pruge na sjeveru i neregulirane rijeke Save na jugu u promatranom razdoblju i dalje bio izoliran. Do vremena kada je Gradsko poglavarstvo primijetilo probleme vezane za naseljavanje na urbanistički neuređenom području doseljenici su već bili dosegnuli kritičnu masu da bi kao udruge građana dobili snagu za ostvarivanje svojih ciljeva u gradskom načelstvu. U radu će se nastojati opisati najvažniji trenuci u oblikovanju južne periferije između dva svjetska rata s posebnim naglaskom na utjecaj uređenja rijeke Save i suodnos gradskih političkih elita i novih stanovnika.

Ključne riječi: Zagreb; južna periferija; 1918. - 1941.; regulacija Save; bespravna gradnja
\end{abstract}

\section{Uvod}

Međuratnu zagrebačku južnu periferiju činili su prostori između Glavnoga željezničkoga kolodvora, željezničke pruge i rijeke Save s već definiranim lukom, ali još uvijek neizgrađenim poplavnim nasipom. Pod južnom periferijom u ovom radu smatra se navedeni prostor omeđen Savskom cestom na zapadu i odvodnim kanalom na istoku, odnosno šire područje Trnja s nizom manjih

* Ovaj je rad financirala Hrvatska zaklada za znanost projektom IP-2016-06-2015. 
kvartova Vrbika, Martinovke, Kruga, Savice ili Volovčice. ${ }^{1}$ Problematika izgradnje i razvitka toga prostora nije nepoznata niti neistražena. Već je bila dio interesa različitih profila autora, od kojih je najviše bilo onih s područja arhitekture, urbanizma i povijesti umjetnosti. Upravo su ti istraživači obradili i problematiku stanovanja na južnoj zagrebačkoj periferiji. Tomislav Timet obradio je stambenu izgradnju u gradu Zagrebu do 1954. , $^{2}$ a socijalnom stanogradnjom u međuratnom Zagrebu i njegovim urbanističkim razvojem bavila se Darja Radović Mahečić. ${ }^{3}$ Zdravstvene prilike u tom razdoblju detaljno je istraživao Željko Dugac. Široki raspon radova o temi razvitka toga prostora u međuraću objavljen je i u časopisu Arhitektonskoga fakulteta Sveučilišta u Zagrebu Prostor. ${ }^{4}$ Od povjesničara se ovom temom najviše bavila Mira Kolar-Dimitrijević. ${ }^{5}$

Prostor koji je svojim najvećim dijelom bio ugrožen godišnjim poplavama Save, na kojemu je nedostajalo osnovne infrastrukture za kvalitetno življenje, a koji je ipak tijekom međuraća bio sve više naseljavan nesumnjivo je intrigantna tema znanstvenoga interesa. U svojoj srži ona pripada socijalnoj i društvenoj povijesti. Ne čudi stoga i zanimanje marksističke historiografije, kada je nastalo najviše historiografskih radova o razvoju Trnja, za priču o stanovnicima Zagreba s dna društvene ljestvice, vrlo često radnicima u obližnjim tvorni-

\footnotetext{
1 Grad je 1928. bio podijeljen na trideset orijentacionih kotareva, a područje južne periferije činili su XVII. kotar Trnje i XVIII. kotar Vrbik.

2 TIMET, Stambena izgradnja Zagreba.

3 RADOVIĆ MAHEČIĆ, Socijalno stanovanje međuratnog Zagreba.

4 Vezano za međuratnu južnu periferiju: ŠTULHOFER, „Prilog istraživanju povijesti izgradnje športsko-rekreacijskih objekata u Zagrebu”, 55-72; ANDRIJEVIĆ, BAŠIĆ, TUTEK, „Željeznica u prostornim planovima grada Zagreba”, 175-186; KAHLE, „Građevinski propisi za grad Zagreb”, 116-129; BARIŠIĆ MARENIĆ, ŚTULHOFER, UCHYTIL, „Zgrada ženske realne gimnazije sestara milosrdnica u Zagrebu”, 284-297; SOKOLIĆ, JUKIĆ, „Zagrebačko naselje Stara Peščenica”, 288-305; SOKOL GOJNIK, GOJNIK, „Crkva Krista Kralja u Zagrebu”, 306321; MATKOVIĆ, OBAD ŚĆITAROCI, „Rijeka Sava s priobaljem u Zagrebu”, 46-59; BARIŠIĆ MARENIĆ, „Gradska klaonica i stočna tržnica u Zagrebu”, 370-383; GAŠPAROVIĆ, SOPINA, „Uloga pejsaža u planiranju grada Zagreba”, 132-145.

5 KOLAR-DIMITRIJEVIĆ, Radni slojevi Zagreba od 1918. do 1931. godine. Kolar-Dimitrijević uredila je 1981. monografiju Zagrebačka općina Trnje u radničkom i komunističkom pokretu i socijalističkoj revoluciji, pripremljenu u Institutu za historiju radničkog pokreta Hrvatske u Zagrebu, a u izdanju Skupštine općine Trnje. O razvoju i povijesti Trnja u međuraću priloge su objavili: OŠTRIĆ, „Urbanizacija Trnja”, 17-27; KOLAR-DIMITRIJEVIĆ, „Stanovništvo Trnja do 1941. godine”, 27-33; ŠIMONĆIĆ-BOBETKO, „Privredni razvoj Trnja do 1941. godine”, 33-51; KOLAR-DIMITRIJEVIĆ, „Grad Zagreb i Trnje do 1941. godine”, 51-57; KOPRIVICA-OŠTRIĆ, „Trnje u organizaciji i djelatnosti KPJ u Zagrebu u razdoblju između dva rata”, 71-93; RAJČEVIĆ, „Revolucionarni omladinski pokret na području Trnja (1918.-1941.)”, 93-109; JANJATOVIĆ, KOLAR-DIMITRIJEVIĆ, „Sindikalni pokret radničke klase Trnja u međuratnom razdoblju”, 109-129; KOLAR-DIMITRIJEVIĆ, OŠTRIĆ, „Radnička kulturna i sportska aktivnost do 1941. godine na području Trnja”, 129-137. Vidi i: KOLAR-DIMITRIJEVIĆ, „Socijalno-ekonomska politika gradske općine Zagreba”, 171-244 i KOLAR-DIMITRIJEVIĆ, „Socijalni slojevi i uvjeti života u južnom dijelu Zagreba", 221-230.
} 
cama sekundarne industrije. Položaj radništva najuže povezanog s prostorom življenja učinio je da su zagrebački kvartovi Trešnjevka i Trnje onda bili oblikovani u mitologizme radničke klase, kada Institut za historiju radničkog pokreta izdaje i dvije monografije o tim gradskim četvrtima. ${ }^{6}$ Međutim, da su stanovnici južne periferije ipak predstavljali širi presjek društvene strukture prikazao je Tomislav Timet još 1961. godine. ${ }^{7}$

Druga dodirna točka s tom temom/prostorom pronalazi se u istraživanjima o gospodarenju vodama zbog ključne uloge Save u oblikovanju životne sredine južne periferije. Upravljanje vodama dugo je opterećivalo razvitak grada Zagreba, a uređenje, točnije „ukroćivanje” Save, koje je u osnovnom dijelu bilo dovršeno do 1918., konačno je omogućilo i njegovo širenje na jug. Istraživanja o regulaciji Save, koja je stoljećima onemogućavala potpuno iskorištavanje prostora južno od željezničke pruge, također su već provođena. ${ }^{8}$

Zanimljiva je opaska autorske skupine Arhitektonskoga fakulteta u Zagrebu, koja je u veljači 2019. za Grad Zagreb izradila studiju Prostorno planska dokumentacija Zagreba i zagrebačkog područja 20. stoljeća i početka 21. stoljeća. Čimbenici koji su utjecali na provedbu planova od 1986. godine, da se „cjelovitim sagledavanjem prostorno planske dokumentacije izrađene kroz posljednja dva stoljeće nameće [se] dojam o kvalitetnom planiranju i razmjerno slaboj realizaciji”. ${ }^{9}$ Ako se ovome mišljenju doda i ono Vjenceslava Richtera da "Zagreb strahuje od eksperimenta", ${ }^{10}$ čini se opravdanim rekonstruirati povijest političkih odluka nasuprot vizijama arhitekata.

Različita društvena i politička uređenja, od kojih su u XX. stoljeću prevladavala ona autoritarne provenijencije, nesumnjivo su izravno utjecala na takvu realizaciju. Gospodarsko-financijska komponenta sigurno je bila ograničavajući element u tome. Stoga se nameće objasniti kontekst političke vlasti u gradu Zagrebu i njegove financijske mogućnosti u ključnom sudaru prostorne anarhije kao nelegalne gradnje i urbanističke sređenosti prema građevinskom

\footnotetext{
$6 \quad$ Institut za historiju radničkog pokreta iz Zagreba 1982. dovršio je i uz izdavačku kuću Spektar iz Zagreba i Skupštinu općine Trešnjevka objavio monografiju Crvena Trešnjevka, koju su uredili Drago Zdunić i Slobodan Žarić, a tekstove je napisalo sedmero znanstvenika iz Instituta. Ta je monografija rađena po istom konceptu kao i prethodna Zagrebačka općina Trnje u radničkom i komunističkom pokretu i socijalističkoj revoluciji (1981.). Vidi: ČEPO, „O dva prethodna rada", 45-48.

7 TIMET, Stambena izgradnja Zagreba, 138.

8 Godine 2010. izašao je tematski broj časopisa Hrvatske vode u kojem su objavljeni odabrani radovi sa znanstvenoga skupa „Rijeka Sava i grad Zagreb - povijesna iskustva i budući razvoj”, održanog 26. listopada 2009. godine. Posebice vidi: SLUKAN ALTIĆ, „Povijest regulacije rijeke Save kod Zagreba", 205-212.

$9 \quad$ ŠMIT et al., Prostorno planska dokumentacija Zagreba, 9.

10 VIDAČKOVIĆ, „Razgovor: Vjenceslav Richter. Zagreb strahuje od eksperimenta”, Vijenac (Zagreb), on-line izdanje, br. 163, 1. 6. 2000., pristup ostvaren 4. 11. 2019., http://www.matica. $\mathrm{hr} / \mathrm{vijenac} / 163 /$ zagreb-strahuje-od-eksperimenta-18099/.
} 
redu. Prikazivanje graditeljske povijesti zagrebačkoga južnog suburbija u međuraću sigurno neće uključivati presjek hrvatske arhitektonske moderne (iako je Meštrović izradio dva, no ipak neostvarena, projekta za crkvu Krista Kralja na Trnju $)^{11}$ ili sličnih nazora u gradogradnji ili stanogradnji.

Uzimajući u obzir da je tema već široko pokrivena, dosadašnja istraživanja u ovaj će se rad uključiti kao pregled. Tako će se nastojati prikazati najvažnije trenutke u izgradnji zagrebačke južne periferije s naglaskom na uređenje Save i željezničke pruge, koje su obrubljivale taj prostor. Na temelju arhivskih dokumenata s već izvedenim istraživanjima nastojat će se dati prilog istraživanjima s naglaskom na odnos gradskih vlasti prema stanovnicima južne periferije između dva svjetska rata. Taj se odnos prije svega zrcalio u tretmanu ilegalno izgrađenih stanova i kuća doseljenika južno od zagrebačkoga Glavnoga kolodvora.

\section{Planovi i realizacije}

Gradski južni dijelovi prvi se put pojavljuju kao osnova urbane regulacije u drugoj polovini XIX. stoljeća i bili su usko povezani sa željeznicom te izgradnjom riječne luke. Prva regulatorna osnova grada Zagreba iz 1865. uključivala je i planiranje prostora između željezničke pruge i Save. U tom planu on nije imao rezidencijalnu namjenu - ona je bila određena za prostor sjeverno od željezničke pruge - nego je bilo predviđeno gospodarsko iskorištavanje teritorija u obliku riječne luke. ${ }^{12}$ Druga regulatorna osnova (1887.) stavila je poplavnu ravnicu između željezničke pruge i Save u „Drugi razdjel” gradskoga prostornog planiranja, prema kojem je taj prostor bio rezerviran za industrijsku, trgovačku namjenu sa skladišnim prostorima uz mogućnost podizanja radničkih naselja, gdje je mogla biti izvedena prizemna gradnja s tek mogućom dogradnjom prvoga kata. ${ }^{13}$ Za razliku od Prvoga i Trećega razdjela, samo je u ovome bila dozvoljena i gradnja nečistih tvornica, i to „istočno od ceste vodeće u Trnje prema majuru grofa Kulmera”, kao i tvornica opeka na najmanje 1000 m udaljenosti od željezničke pruge između potoka Črnomerca i Medveščaka. ${ }^{14}$

U to je vrijeme potencijalni građevinski prostor južne periferije i dalje bio izvan planskih razmišljanja gradskih službi, a na prostor se prvenstveno gledalo kao na rekreativni i industrijski. Budući da nije bilo regulatornoga plana za

11 Opširnije u: SOKOL GOJNIK, GOJNIK, „Crkva Krista Kralja u Zagrebu”, 306-321. Katolička crkva vodila je i karitativnu skrb na području Trnja. Tu je 1933. otvoreno Dječje sklonište za oko 150 djece, a između 1935. i 1938. osnovano je sedam novih župa, koje su sve bile južno od željezničke pruge. Vidi: Župa Krista Kralja.

12 RADOVIĆ MAHEČIĆ, Socijalno stanovanje međuratnog Zagreba, 14, 15.

13 Isto, 19; JURIĆ, „Građevni redovi i regulatorno planiranje Zagreba”, 23.

14 JURIĆ, „Građevni redovi i regulatorno planiranje Zagreba”, 24. 
dijelove između željezničke pruge i Save, nije bilo nikakvih temelja za izradu generalne, a još manje detaljne osnove koja bi omogućila bilo kakvu gradnju. Nije se razmišljalo o razvoju južnih dijelova dok se ne izgrade gradski prostori u središtu i na sjeveru. ${ }^{15}$ Razlozi su bili očiti, a nekoliko godina poslije Lenuci ih je objasnio neuređenošću vodotoka Save i potoka na tom području, lošim prometnim položajem u odnosu na grad zbog smještaja pruge, ali i nepostojećom infrastrukturom, od čega bi, zbog prostornih uvjeta, prije svega kanalizacija trebala osigurati kvalitetnu odvodnju prije izgradnje bilo kakvih masovnijih objekata. Milan Lenuci, tadašnji voditelj Gradskoga građevnog ureda, tim je argumentima 1904. bio odgovorio Zemaljskoj vladi, koja je pritisnuta sve većim naseljavanjem i zahtjevima za izdavanje građevinskih dozvola na južnoj periferiji naložila Gradu izradu potrebnih regulacijskih osnova u roku od šest mjeseci. ${ }^{16}$

U tom je trenutku Lenuci nastojao Zemaljsku vladu odgovoriti od takva plana širenja grada, predlažući im „povoljnije i zdravije predjele” sjeverno od željezničke pruge. ${ }^{17}$ Podrška takvu razmišljanju bio je nepovoljni položaj željezničke pruge kao i još uvijek neregulirana rijeka Sava. Lenuci je za Zemaljsku vladu 1907. izradio i regulaciju grada u kojoj je širenje Zagreba bilo usmjereno na jugoistok, koji je trebao postati industrijska zona s riječnom lukom, ali i četvrt s radničkim stanovima. ${ }^{18}$

Regulacija Save otpočela je 1896., kada su gradske vlasti već počele uvoditi južnu periferiju u natruhe budućih regulacijskih planova. Tek godinu dana od vrlo ozbiljnih poplava Save, ali i zagrebačkih gradskih potoka, Zemaljska vlada osnovala je Građevnu upravu za regulaciju Save. ${ }^{19}$ Regulacijski plan Save bio je načinjen na temeljima tadašnjih paradigmi „ispravljača rijeka”, aktualnih u trenutačnim dostignućima njemačkih i austrijskih hidrografskih inženjera. ${ }^{20}$ Zadani postulat „ispravljača” bio je da rijeka ne treba imati više od jednoga korita. Ta su se saznanja prelijevala i u monarhijsku provinciju preko školovanja ili stručnoga usavršavanja inženjera iz Hrvatske i Slavonije. To je bio slučaj i s nositeljem projekta regulacije Save Augustom pl. Pisačićem, koji je u svoj projekt prenio spoznaje dobivene upravo radeći na ispravljanju rijeke Isar u

15 KNEŽEVIĆ, „Regulatorna osnova Milana Lenucija za dio Zagreba od željezničke pruge do rijeke Save iz 1907.“, 176, 177.

16 Isto, 176.

17 RADOVIĆ MAHEČIĆ, Socijalno stanovanje međuratnog Zagreba, 27.

18 Isto. KNEŽEVIĆ, „Regulatorna osnova Milana Lenucija za dio Zagreba od željezničke pruge do rijeke Save iz 1907.“

19 SLUKAN ALTIĆ, „Povijest regulacije rijeke Save kod Zagreba”, 208.

20 ČAVLOVIĆ, LOVRENČIĆ, SEVŠEK, „Dvije 'polovice’ Novog Zagreba”, 462. 
Bavarskoj. ${ }^{21}$ Model koji je tada prihvaćen odredio je formiranje Save u jednom vodotoku pravilnoga luka u simetričnom polumjeru od $800 \mathrm{~m}$, čija je središnja os bila postavljena kroz zagrebačko srednjovjekovno središte Gornjega grada. ${ }^{22}$ Sava je južno od željezničke pruge i istočno od Savske ceste stavljena u planirani luk već do 1906., kada je Gradsko poglavarstvo znatno promijenilo svoj stav prema južnoj periferiji. ${ }^{23}$

Pisačić i Stjepan Bukl, obojica inženjeri građevinarstva, izradili su 1919. i precizno izvješće o stanju regulacije u Zagrebu, u kojemu je bilo vidljivo da je savski luk između željezničkoga mosta (Savske ulice) i Žitnjaka obložen kamenom u obali, ali i da na tom području nije bilo izgrađenoga nasipa. ${ }^{24}$ Uslijed neodržavanja već izgrađenih dijelova zapadno od željezničkoga mosta, kao i spomenutoga nasipa, održavanje i donekle uređenoga korita bilo je otežano. Iako još nije postojao nasip, nekakva regularnost u obrani od poplava već se nagoviještala, što je dodatno činilo južne gradske prostore privlačnima za naseljavanje. Taj prostor još uvijek nije imao određeni urbanistički plan regulacije, no izvjesno je da su gradske građevinske službe ipak razmišljale o njegovu potencijalu, kao i da su nakon početka regulacije Save jasno upozorile na glavnoga kočničara razvoja - željeznicu.

Sigurnost južne periferije od poplava nije bila osigurana sve do 30-ih godina, a i onda je bila na minimumu. Zbog nedovoljnih ulaganja u izgradnju nasipa dijelovi Trnja bili su katastrofalno poplavljivani i 1923., 1925., 1930., 1933. i 1936. godine. ${ }^{25}$ Grad je za ubrzanje uređenja Save od 1898. naplaćivao i poseban porez za regulaciju Save, ali Gradska skupština zaključila je 1923. da je „novac sav potrošen, a za regulaciju učinjeno vrlo malo”. ${ }^{26}$ Nakon stvaranja Kraljevine Srba, Hrvata i Slovenaca ulaganja u izgradnju i pojačanje nasipa i dalje su bila nedovoljna. Tako je velika poplava krajem studenoga 1923. odnijela oko 500 m nasipa izgrađenog tek mjesec dana prije. ${ }^{27}$ Dogodilo se to uslijed

\footnotetext{
21 Pisačić je 1893. objavio i opširno izvješće o svojem „putovanju po Njemačkoj” i iskustvu na uređenju vodotoka u Bavarskoj: Vodogradjevine na gornjem Renu i gornjem Dunavu i na pritocima Kinzig, Iller, Isar, Inn: sa osamdeset $i$ devet listova nacrta (Zagreb: Kr. hrv.-slav.-dalm. zemaljska vlada, 1893).

22 ČAVLOVIĆ, LOVRENČIĆ, SEVŠEK, „Dvije 'polovice’ Novog Zagreba”, 463.

23 SLUKAN ALTIĆ, „Povijest regulacije rijeke Save kod Zagreba”, 210.

24 Isto.

25 Primjerice, za izgradnju nasipa na desnoj obali Save kod Kajzerice Gradsko poglavarstvo odobrilo je 40.000 kruna. Za 1922. planirano je Generalnoj inspekciji voda doprinijeti s 500.000 dinara za izgradnju nasipa od željezničkoga mosta do Trnja te još 125.000 dinara za izgradnju obostranih nasipa uz potok Kunišćak. Sljedeće gradsko ulaganje u nasip bilo je tek 1925. - oko 79.000 dinara za pojačanje nasipa u Horvatima (od Savskoga mosta do Črnomerca) u duljini od $2730 \mathrm{~m}$ (Zagreb godine 1913. - 1925., 1. dio, 34 i 2. dio, 265).

26 Isto, 1. dio, 27.

27 Osim nasipa bile su uništene i brojne kuće; visina vode u najkritičnijem trenutku (30. studenog 1923.) dosezala je 4,12 m. Inicirano je i više akcija za prikupljanje dobrotvornih sredstava.
} 
financijske nemogućnosti izgradnje nasipa u ukupnoj planiranoj duljini od 1 $\mathrm{km}$, pa je u poplavi odneseno i dotadašnje ulaganje od 5,5 milijuna kruna. Razlog je bio u isplati tek 100.000 dinara iz državnoga proračuna od planiranih čak milijun dinara. ${ }^{28}$ Načelnik Građevne uprave za regulaciju Save u Zagrebu Franjo Abramović izjavio je polovinom 20-ih godina da je od 1918. započelo doba u kojem „počimlju nedovršene građevine usljed raznih okolnosti propadati, tako da je cjelokupan rad bio uništen, što je dovelo regulatorne gradnje u ono očajno stanje u kojem se danas nalaze" ${ }^{29}$

Izgradnja trnjanskoga nasipa nastavljena je pojačano nakon 1925., posebice u mandatima Vjekoslava Heinzela, Ive Krbeka, pa i Rudolfa Erbera, i do sredine 30-ih godina ipak je bila dovršena i pružila južnim gradskim prostorima barem nekakvu obranu od Save, što je bio i posljednji od većih zahvata na njezinoj regulaciji u međuraću. ${ }^{30}$ Do osnutka Banovine Hrvatske u proračunu Tehničke sekcije za regulaciju Save u Zagrebu bilo je predviđeno 100 do 200 tisuća dinara godišnje. Znatan pomak u uređenju Save dogodio se za vrijeme Banovine Hrvatske, kada je u proračunu za 1940. bilo predviđeno 6,5 milijuna dinara te zajam od još 5 milijuna dinara za regulaciju gornjega toka Save. ${ }^{31}$

Gradske su vlasti na područje južne periferije često gledale i kao na potencijalno iskoristivo zemljište, ali čini se više tek u smislu rekreacije, a ne za naseljavanje. Naglašavajući potrebu izgradnje trnjanskoga nasipa, skupština je 1919. odlučila da se Ministarstvu poljoprivrede i voda i Kraljevskoj zemaljskoj vladi uputi predstavka „za što skoriju izvedbu savskog nasipa u pravcu od željezničkog mosta do Trnjančine, da bi se zapriječila česta i tako štetna poplava onog predjela i omogućilo bolje izrabljivanje onih zemljišta kao i izvedba novog savskog kupališta”. ${ }^{32}$ Rekreativna uloga južne periferije bila je možda i najprisutnija, posebice zbog gradskoga kupališta, iako je većina gradskih sportskih i rekreativnih prostora bila na Šalati, u Maksimiru i na Medvednici. ${ }^{33} \mathrm{Uz}$ kupalište, na tom prostoru bio je i niz drugih sportsko-rekreativnih objekata:

U pomoći su ponajviše sudjelovali ostali gradovi (Karlovac s 25.000 dinara, Bjelovar, Šibenik i Petrinja s 10.000 dinara, Petrovaradin i Daruvar s 5.000 dinara, Požega i Čakovec s 2.500 dinara). Građanima je upućen i zahtjev za donaciju odjeće i namirnica unesrećenim stanovnicima Trnja. Odazvalo ih se tek 75 poklonivši 766 odjevnih predmeta, za koje je ustanovljeno da je „veliki dio (poklonjene) robe neuporabljiv”. Različitim akcijama (gradonačelnikove supruge Berte Heinzel, vojnih časnika, gradskoga redarstva, uprave Jutarnjega lista, osobnim donacijama) ukupno je prikupljeno 1.191.869 dinara, od čega je na troškove poplave do 21. prosinca 1923. utrošeno oko 800.000 dinara (Zagreb godine 1913. - 1925., 1. dio, 27, 123).

28 Isto, 27.

29 MATKOVIĆ, „Uređenje rijeke Save na području oko Zagreba”, 226.

30 SLUKAN ALTIĆ, „Povijest regulacije rijeke Save kod Zagreba”, 210-211.

31 Godišnjak banske vlasti Banovine Hrvatske, 171.

32 Zagreb godine 1913. - 1925., 1. dio, 19.

33 ŠTULHOFER, „Prilog istraživanju povijesti izgradnje športsko-rekreacijskih objekata u Zagrebu", 55-72. 
sportska igrališta „Građanski”, „Viktorija”, „Tipografija”, „Penkala”, moto trkalište „Miramare”, teniski tereni Zagrebačkoga teniskog kluba, koji su zimi postajali klizalište. ${ }^{34}$ Takva joj je uloga bila namijenjena i u nacrtu glavnoga regulatornog plana iz 1931. (odobrenog 1940.), kada je prostor uz Savu cijelom dužinom grada i na lijevoj i na desnoj obali bio predviđen za izgradnju centra rekreacije izmiješanog sa šumsko-parkovnim predjelima. ${ }^{35}$

Nacrt Zagreba s elementima regulacije iz 1923. djelomično je ušao i u okvire južne periferije, ali nije donio regulaciju izgradnje prostora na koji se već sve više doseljavalo. Uz regulaciju Save i početak izgradnje nasipa u Trnju urbanizaciju je od 1928. pratilo i nastojanje gradskih vlasti da napokon izrade generalni urbanistički plan, kada je osnovan Odsjek za regulaciju grada, ali i Odbor za pripremu generalne regulatorne osnove. ${ }^{36}$ Ta su nastojanja prvi put jasno i nedvosmisleno uključivala i razvoj prostora južno od željezničke pruge: „Ovom će se osnovom imati riješiti sva ona pitanja, koja smetaju normalnom i racionalnom razvitku grada, a to je u prvom redu željeznički problem; trebat će riješiti pitanje prolaznih cesta i prometa uopće, pitanje Save i savske luke; ova će osnova morati korigirati neprirodni i štetni longitudinalni razvoj grada." 37 Ta važna namjera prethodila je raspisivanju međunarodnoga natječaja za izradu glavnoga regulatornog plana 1930., koji je rezultirao idejom/opredjeljenjem za stapanje Donjega grada i Trnja, nastavljanje zelenih parkovnih površina Zrinjevca prema Savi i pretvaranje toga prostora u novo gradsko središte. ${ }^{38} \mathrm{Na}$ temelju pristiglih radova na natječaj ipak se do 1936./37. razvio novi generalni regulatorni plan Zagreba, koji je nakon niza izmjena i stanki konačno bio odobren tek krajem travnja 1940., kada ga je dopunio i odobrio povjerenik banske vlasti Mate Starčević. Za njegovu primjenu više nije bilo vremena ni mogućnosti. Prema zakonu o toj regulatornoj osnovi, bio je osnovan i „regulacioni fond”, no njegovi prihodi bili su tako maleni da nije mogao „ni izdaleka odgovarati namijenjenoj svrsi”. ${ }^{99}$ Gradske financijske nemogućnosti bile su i osnovnim razlogom da grad ni u tom trenutku nije imao dovoljan broj javnih objekata poput škola, da su ceste bile neuređene, a kanalizacijski kanali i dalje nenadsvođeni. ${ }^{40} \mathrm{U}$ međuraću se grad ipak razvijao u smjeru istok-zapad, prepreke na jugu bile su prevelike. Željeznička pruga i

\footnotetext{
34 OŠTRIĆ, „Urbanizacija Trnja”, 17-27 (25).

35 GAŠPAROVIĆ, SOPINA, „Uloga pejsaža u planiranju grada Zagreba”, 136.

36 RADOVIĆ MAHEČIĆ, Socijalno stanovanje međuratnog Zagreba, 50, 70.

37 ANDRIJEVIĆ, BAŠIĆ, TUTEK, „Željeznica u prostornim planovima grada Zagreba”, 177.

38 Isto, 178.

39 HR-DAZG-10, Građevni odsjek (dalje: 14), Građenje kuća bez dozvole i kuća na tuđem zemljištu, Broj: 1713-III-Int-1941., 71/5.

40 Isto. Prvo asfaltiranje na području Trnja dogodilo se tek 1925., kada je asfaltiran podvožnjak u Miramarskoj ulici izgrađen 1912. godine.
} 
još uvijek prijeteća Sava s rukavcima, ali i nedostatak regulacijskih planova za to područje odredili su ga kao prostor nelegalne izgradnje. ${ }^{41}$

\section{Prilike i rješenja}

Između dva svjetska rata taj prostor doživljava vrlo snažan rast stanovništva. Od 1910. do 1931. broj stanovnika porastao je za čak 296,3 \%, od 4572 na 18123 stanovnika, što je činilo $12,72 \%$ ukupne gradske populacije. ${ }^{42} \mathrm{Za}$ razliku od Trešnjevke, kamo se tijekom 30-ih godina naseljava i građansko-činovnički sloj stanovnika zbog izgradnje gradskih stanova i tramvajske pruge, na prometno izoliranom Trnju to se do početka Drugoga svjetskog rata događalo u manjoj mjeri. ${ }^{43}$ Južno od pruge naseljavaju se pretežno siromašniji turopoljski seljaci ili oni iz sjeverne Hrvatske. ${ }^{44}$ Njihovo podrijetlo posredno su potvrdili iz Odbora za imenovanje ulica kada su 1927. dio ulica na području južne periferije nazvali imenima nekih zagorskih mjesta i poznatijih sela istočno od Zagreba „iz kojih su potjecali mnogi Zagrepčani”. ${ }^{45}$ Isti odbor smatrao je i da za „nove ulice na gradskoj periferiji, osobito u predjelima južno od željezničke pruge, ne bi nikako bila zgodna imena znamenitih ljudi, jer su te ulice najvećim dijelom vrlo neugledne, a osim toga su nastale bez obzira na ikakvu regulatornu osnovu". ${ }^{46}$

Kronična nestašica stanova koja je i uzrokovala takvo naseljavanje južne periferije vladala je u Zagrebu još od početka XX. stoljeća, ali se nakon Prvoga svjetskog rata višestruko povećavala. ${ }^{47}$ Međutim, Zagreb je u dvadesetak godina po brojnosti novoizgrađenih stanova nadmašio i cjelokupno razdoblje

\footnotetext{
41 TIMET, Stambena izgradnja Zagreba, 124.

42 Početkom XX. stoljeća udio stanovništva Trnja u stanovništvu Zagreba iznosio je 1,8 \%, a neposredno pred Prvi svjetski rat 3,5 \%. KOLAR-DIMITRIJEVIĆ, „Stanovništvo Trnja do 1941. godine", 27-33 (28).

43 Isto, 32.

44 ČAVLOVIĆ, LOVRENČIĆ, SEVŠEK, „Dvije 'polovice’ Novog Zagreba”, 496.

45 HR-DAZ-10, Predsjedništvo, Spisi o imenovanju ulica i trgova, Koncept knjige „Ulice, trgovi, ceste, šetališta u sl. kr. gradu Zagrebu 1929. god., s podjelom na orjentacione kotare“, str. V., PRS. 214

46 Isto.

47 Stanarinski ured sa zadatkom rekviriranja i dodjeljivanja potrebnih stanova na području grada počeo je djelovati 6. prosinca 1918., do 1. siječnja 1919. predano je 5180 molbi za stan, a udovoljeno je u 1996 slučajeva. Pozvano je 8000 stranaca da opravdaju svoj boravak u Zagrebu, a 200 ih je bilo pozvano da napuste grad. Godine 1923. reorganiziran je u Ured stambene vlasti, koji je konačno ukinut Zakonom o stanovima 1925., nakon čega su vlasnici mogli slobodno raspolagati svojom imovinom, a najviše stanarine više nisu bile zakonom propisane (KOLAR-DIMITRIJEVIĆ, Radni slojevi Zagreba od 1918. do 1931. godine, 136-138). Godine 1926. osnovan je i Stambeni odbor, čiji je zadatak bio utvrđivanje stvarnoga broja stanova na području grada. Odbor je ukinut 1927., a njegove poslove preuzeo je I. gospodarski odsjek. ČENGIĆ, Gradsko poglavarstvo Zagreb 1850. - 1945., 145.
} 
u Austro-Ugarskoj: između 1919. i 1940. izgrađeno ih je 50 722, a Tomislav Timet naveo je da ih je bilo točno dva i pol puta više negoli ih je Zagreb imao krajem 1918. godine. ${ }^{48}$ Ako se uzme u obzir da je u istom razdoblju broj stanovnika grada narastao za oko jedan i pol puta, moglo bi se zaključiti da stanova i nije nedostajalo. Glavni nedostatak tih stanova bila je njihova veličina, odnosno premalen broj soba po stanovniku. ${ }^{49}$ Logično, u skučenim uvjetima i kvaliteta življenja bila je lošija, a čini se da su takvi stanovi prostorno bili rašireniji na periferiji nego na gradskom sjeveru. ${ }^{50}$

I zdravstvene prilike ondje su bile nepovoljnije nego u ostatku grada. Upravo su na područjima s čestim poplavama bili mnogo učestaliji i brojniji slučajevi bronhitisa, što se posebice odnosilo na Horvate i Trnje. ${ }^{51}$ Međutim, česte poplave nisu spriječile nova naseljavanja niti nagnale one već doseljene na odlazak. Primjerice, u vrijeme poplave krajem studenoga 1923. stanovnici ugrožene južne periferije nisu željeli napustiti svoje domove zbog straha od pljačke imovine, a i nakon niza poplavljenih kuća tek se 12 ljudi prijavilo u pripremljena gradska skloništa. ${ }^{52}$

Iako je Paromlin bio prva tvornica na tom području, najveći i najvažniji poslodavac na Trnju, posebice u međuraću, bila je željeznica, odnosno Željeznička radionica za remont lokomotiva i vagona. Željeznica je tako postala bitno vezana uz trnjansko stanovništvo odmah početkom XX. stoljeća, a ondje se formira i veća željezničarska kolonija. Prvih nekoliko godina Kraljevine Srba, Hrvata i Slovenaca ona se znatno povećavala doseljavanjem novih radnika, gdje je oko 280 obitelji živjelo u nekoliko desetaka vagona postavljenih na dva zatvorena kolosijeka južno od kolodvora. ${ }^{53} \mathrm{Uz}$ Paromlin i Željezničku radionicu na južnoj periferiji nalazila se i Tvornica papira, Plinara, Prva hrvatska tvornica za elektroindustriju Ivan Paspa i sinovi te Tvornica turpija Faber. ${ }^{54}$ Oko 18000 stanovnika južne periferije bilo je radničkih zanimanja, od kojih je oko 8000 imalo i zaposlenje na Trnju. ${ }^{55}$ Međutim, primjetno je da je više od polovice radnika zaposlenje imalo izvan toga područja, u "gradu”.

Takav razvoj industrije nikako nije mogao pratiti pojačano useljavanje. Tek uspoređujući apsolutne brojeve iz popisa stanovništva vidi se da se u grad mehanički doseljavalo znatno više imigranata negoli ih je tržište rada moglo

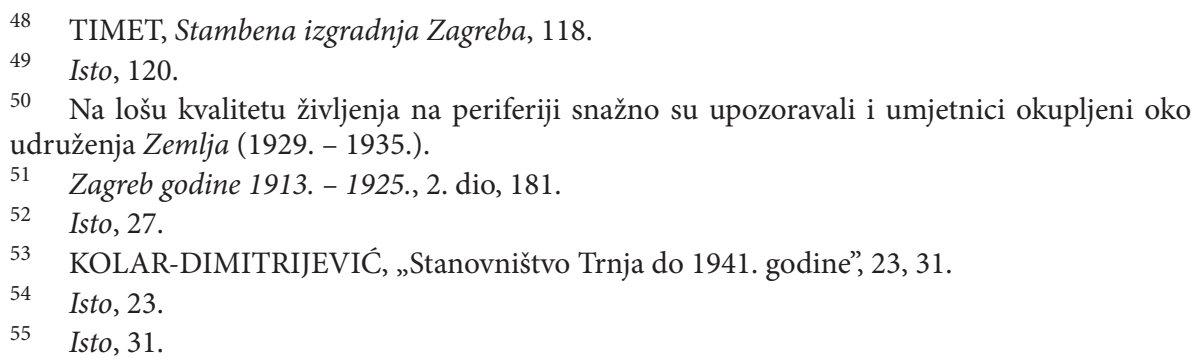


prihvatiti. Posljedično je uz kronično siromaštvo uslijed nedostatka posla i nedostatak stanova, posebice jeftinih, postao kroničan. Nastojeći ublažiti tu nestašicu, gradske su vlasti između 1921. i 1934. podigle 134 stambene zgrade s 1334 stana i 1659 soba, u kojima je prema popisu iz 1931. živjelo 5468 ljudi. ${ }^{56}$ Jasno je međutim da ta ulaganja nisu mogla osigurati dovoljan broj stanova, a jeftinu alternativu doseljenici su onda nalazili na južnoj periferiji. Ti su se gradski stanovi usto i iznajmljivali, što je Gradsko poglavarstvo stavljalo u položaj najvećega „kućevlasnika” u gradu, a stanarine i prihodi godišnje su se povećavali, posebice od 1925. i liberalizacije stanarskoga tržišta nakon Zakona o stanovima ${ }^{57}$ Gradsko poglavarstvo očito nije smatralo da bi i povećanje stambenoga fonda u vlasništvu Grada popravilo situaciju jer je smatralo da je „u psihi našega naroda [je] uvrežena želja i nastojanje, da si stvori svoju kućicu, svoju slobodicu [koji] I tako nije strahovao pred ničim i sebi kućicu izgradio". ${ }^{58}$ Od trideset orijentacijskih kotareva početkom 30-ih godina najviše kuća nalazilo se na Trešnjevci. Tu je na 1 ha dolazilo 12,94 kuća/zgrada. Najmanje kuća bilo je na Žitnjaku, tek 0,09/ha. Vrbik je imao 3,76 kuća po hektaru i bio je 11. gradski kotar prema izgrađenosti, Trnje je imalo 2,67 kuća na 1 ha i bilo je na 13. mjestu. Sigečica, najistočniji kotar južne periferije, imala je na hektaru tek 0,67 kuća i bila je na 23. mjestu. ${ }^{59}$ Najnaseljeniji kotar u istom razdoblju bio je Donji grad s 224,44 stanovnika po hektaru. Najmanje naseljen bio je Žitnjak s 0,52 stanovnika po hektaru. Vrbik i Trnje i ovdje su bili u sredini. Vrbik s 36,98 stanovnika bio je 11., a Trnje s njih 28,29 na 15. mjestu. Sigečica je prema ovom pokazatelju bila na 22. mjestu i imala je tek 9 stanovnika na 1 ha. ${ }^{60}$

Razliku u strukturi stanovništva pokazuju i podaci o broju domaćinstava na jednu zgradu/kuću. U Donjem gradu na jednu građevinu dolazilo je najviše domaćinstva $(6,05)$, što daje zaključiti da se ondje radilo o većim zgradama.

56 HR-DAZG-10-14, Građenje kuća bez dozvole i kuća na tuđem zemljištu, Broj: 1713-IIIInt-1941., kt. 71/5. Darja Radović Mahečić navodi da je između dva svjetska rata podignuto petnaestak naselja. Jedanaest ih je sagradilo gradsko načelstvo, a četiri su podignuta privatnim ili ulaganjima poduzeća (naselje Arko, Željeznička kolonija, naselje Prve hrvatske štedionice, Cvjetno naselje za činovnike). Gradska naselja i kuće sa stanovima bili su: gradske kuće na Ciglani, stanovi za deložirane na Klaoničkoj cesti, mali stanovi na Kanalu, gradske kuće na Kanalu, mali stanovi na Laščinščaku iza živodernice, gradske kuće u Meršićevoj ulici, Plinarsko naselje, provizorni stanovi na Selskoj cesti, mali stanovi na Gogoljinu brijegu, naselje Istrana i invalida na Selskoj cesti, stanovi i ateljei za umjetnike na Voćarskoj cesti. RADOVIĆ MAHEČIĆ, „Socijalno stanovanje međuratnog Zagreba”, 141-155. Usp. i: RADOVIĆ MAHEČIĆ, Socijalno stanovanje međuratnog Zagreba.

57 Opširnije o gradskoj stambenoj politici vidi u: KOLAR-DIMITRIJEVIĆ, Radni slojevi Zagreba od 1918. do 1931. godine, 139-141.

58 HR-DAZG-10-14, Prijedlog za male kuće na periferiji za regulatorni odbor gradskog zastupstva od 28. svibnja 1929. odnosno za izvanrednu skupštinu gradskog zastupstva od 29. svibnja $1929 ., 71 / 5$.

59 Mali statistički priručnik grada Zagreba 1931., 23.

60 Isto. 
Najmanje ih je bilo na Žitnjaku - 1,11. Sigečica $(2,88)$, Vrbik $(2,57)$ i Trnje $(2,5)$ bili su podjednaki prema broju domaćinstava na jednu zgradu. ${ }^{61}$ Kada se uzme u obzir broj članova jednoga kućanstva, onda je Žitnjak imao najviše članova $(5,29)$, a Donji grad najmanje $(3,59)$. Južna periferija bila je i ovdje podjednaka. Kućanstvo na Trnju prosječno je činilo 4,18 osoba, na Sigečici njih 4,16, a na Vrbiku 3,77 osoba. ${ }^{62}$

Upravo u takvim uvjetima oblikovala se i najveća karakteristika južne periferije, koja je desetljećima opterećivala odnos s Poglavarstvom. Bila je to neplanska, često i bespravna gradnja na nereguliranom gradskom prostoru. Međutim, ti doseljenici tek su u manjem broju slučajeva mogli sami financirati bilo kakvu izgradnju, a kredit bankarskih institucija nije se mogao dobiti bez građevinske dozvole. Procjenjuje se da su takve kuće bile i do šest puta jeftinije od onih legalno izgrađenih. ${ }^{63}$ Posljedica takvih odnosa bila je pojava stanarskih špekulanata, poduzetnika koji su na jeftinome zemljištu gradili često i nekvalitetne stanove, koje su onda iznajmljivali po znatno povoljnijim cijenama negoli su to bili stanovi sjeverno od pruge. Uz pojačani priljev stanovništva, ali ne i razvoj komunalne infrastrukture, južna periferija postajala je područje pogoršanih tehničko-higijenskih životnih uvjeta.

Takvo naseljavanje događalo se u oko 75 \% slučajeva tako da su doseljenici dolazili na proizvoljno rasparcelirana zemljišta, koja im je vlasnik prodavao ili davao u mjesečni ili godišnji zakup s pravom izgradnje kuće. Prema jednom izvješću Gradskoga građevinskog odjela iz 1934., najam je, vjerojatno u obliku otplate, bio od 50 do 100 dinara mjesečno, a prosječna primanja doseljenika „malih ljudi” bila su oko 800 do 1.000 dinara. ${ }^{64}$ Najam stanova u gradu bio je od 200 do 400 dinara, s time da su na periferiji uz kuću napravljenu materijalom s otplatom na rate imali još i dovoljno zemlje za obradu vrta, a kuće s više stanova najčešće su služile za daljnji najam. ${ }^{65}$

Sljedeći grafikon pokazuje primjer jednoga takva slučaja izgradnje. $\mathrm{Na}$ području Martinovke od I. do V. ulice pružalo se zemljište Vilima Agića na koje se nakon parcelacije naselilo 59 novih vlasnika, vjerojatno s obiteljima, od kojih je 20 još bilo u statusu najmoprimca. Novi naseljenici nisu većinom pri-

\footnotetext{
61 Isto, 24.

62 Isto, 25.

63 RADOVIĆ MAHEČIĆ, Socijalno stanovanje međuratnog Zagreba, 59; TIMET, Stambena izgradnja Zagreba, 172.

64 HR-DAZG-10-14, Izvještaj o gradnjama sagrađenih bez oblasne dozvole u godini 1934. 71/5. Npr. prema procjenama Zlate Vuksanović-Macura za 1932., u Beogradu su se bijednima mogle smatrati obitelji s mjesečnim primanjima ispod 1.000 dinara, a gospodarski jake bile su one s primanjima iznad 3.000 dinara. Minimalna izdvajanja za prosječnu obitelj u Beogradu iznosila su 1.800 dinara. VUKSANOVIĆ-MACURA, Život na ivici, 23.

65 HR-DAZG-10-14, Izvještaj o gradnjama sagrađenih bez oblasne dozvole u godini 1934., $71 / 5$.
} 
padali radništvu, a presjek zanimanja pokazuje da su obavljali upravo tipične gradske poslove i usluge, od obrtnika, javnih službenika, radnika i, naravno, djelatnika željeznice. Ti podaci mogu poslužiti tek za zorniji prikaz složenosti socijalno-demografske slike južne periferije.

Prosječan broj soba u stanu prema zanimanjima vlasnika na Martinovki između I. i V. ulice (1928.)

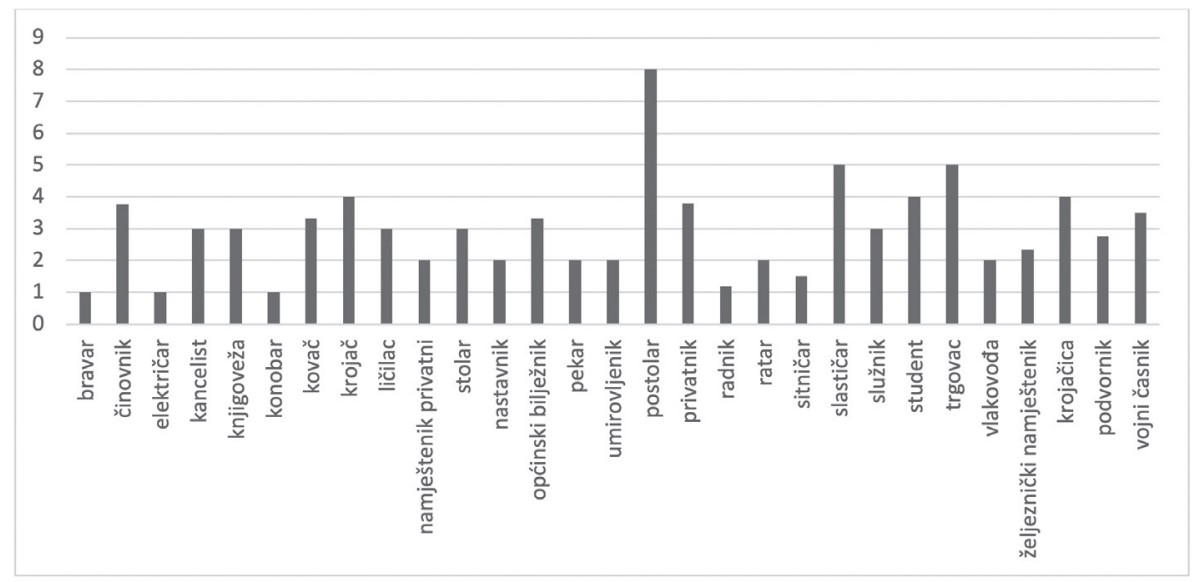

(Izvor: HR-DAZG-10-14, Zamolba stanovnika Martinovke Gradskom poglavarstvu od 6. ožujka 1928., kt. 71/5.)

Veliki broj doseljenika postajao je sve jače organizirana skupina koju se moralo uzimati u obzir pri postupanju s tim prostorom. ${ }^{66}$ Tamošnji građani organizirali su se u komunalna udruženja, koja su mogla ostvariti i jači pritisak, a posredno i politički utjecaj u traženju ozakonjenja bespravno izgrađenih kuća. Upozoravajući na vlastiti položaj i stanje, a tražeći od Gradskoga poglavarstva naknadne građevinske dozvole, ujedinjeni građani dijelova Trnja (Martinovke, Vrbika, kraja oko Viktorijina igrališta, desne strane Građanskoga igrališta i Maloga Beograda kraj Tipografijina igrališta) opravdavali su se u ožujku 1928. Gradskom poglavarstvu da su svoje kućice morali podizati prisiljeni stambenom krizom. Budući da nisu mogli dobiti bankovne kredite, uzimali su ih od lihvara uz kamate 20-30 \% i nužno im je trebalo reprogrami-

66 Stanovnici s neriješenim stambenim pitanjem okupili su se 1927. u Stanarinski blok i sudjelovali na gradskim izborima. Usp. RADONIĆ VRANJKOVIĆ, „Gradski i parlamentarni izbori u Zagrebu", 249-274 (267). 
ranje tih kredita, a to je u službenim bankarskim ustanovama podrazumijevalo građevinske dozvole. ${ }^{67}$

Od 1929. i uloga gradonačelnika bila je znatno izmijenjena. Nakon proglašenja kraljeve diktature gradonačelnike i gradsko načelstvo postavljao je ministar unutarnjih poslova. Budući da su članovi gradske uprave bili izravno imenovani, oporbe nije bilo, pa je i uloga gradonačelnika posljedično još više ojačala. Petar Živković, general, predsjednik vlade i ministar unutarnjih poslova u prvoj vladi diktature, na mjestu zagrebačkoga gradonačelnika ostavio je Stjepana Srkulja, bivšega člana Hrvatske zajednice, poznatog kao „kompromisnog" čovjeka. ${ }^{68} \mathrm{Ni}$ u njegovu razdoblju nije došlo do većega uređenja južne periferije jer se očekivalo da će se veliki dio rušiti nakon donošenja generalnoga urbanističkog plana. Politička elita za vrijeme njegova mandata, kao i prije, na periferiju je odlazila tek po službenoj dužnosti, a Srkulj nikada nije službeno posjetio južnu periferiju. ${ }^{69}$

Promjene u pristupu južnoj periferiji zabilježene su od mandata Ive Krbeka (1932. - 1934.), koji je funkcionirao unutar oktroiranoga parlamentarizma nakon 1932. godine. Iako je pripadao prorežimskoj grupaciji, bio je prvi načelnik koji je sustavno obilazio periferiju, pa i Trnje, a znakovito je da je upravo u njegovu mandatu bio pokrenut i list koji je upozoravao na probleme perifernih gradskih četvrti, Glas Trešnjevke. U okvirima gospodarske krize koja je dovela do snažne štednje Krbek je ipak nastojao urediti ceste te omogućiti i komunalno funkcioniranje gradske periferije. Primjerice, u njegovu mandatu (1933.) bila je pokrenuta gradska autobusna linija na Trnju. Ponovno se intenzivnije raspravljalo i o podjeli građevinskih dozvola stanovnicima periferije. Krbekov podnačelnik Jakob Pavlina snažno je branio odluku gradskoga načelstva o njihovu izdavanju. Snažnija briga o južnoj periferiji nije se mogla započeti bez urbanističkoga plana, na čijem je donošenju počelo raditi još Poglavarstvo za vrijeme Heinzela. Iako je Srkulj bio i ministar građevina, dakle na čelu ustanove koja je u konačnici odobravala regulatorne osnove, u njegovu mandatu taj se proces nije znatnije ubrzao. Krbek se pojačano brinuo i o nastavku uređenja te održavanju savskoga nasipa. Poplava koja je tijekom 1933. sedam tjedana ugrožavala grad navela ga je na zaključak da bez dovršetka uređenja Save „o apsolutnoj sigurnosti ne može biti ni govora”. ${ }^{70}$ Međutim, nedostatak novca

67 HR-DAZG-10-14, Zamolba stanovnika Martinovke Gradskom poglavarstvu od 6. ožujka 1928., 71/5.

68 KOLAR-DIMITRIJEVIĆ, „Socijalno-ekonomska politika gradske općine Zagreba”, 173174. Stjepan Srkulj nakon gradonačelničkoga mandata bio je ministar građevina u tri jugoslavenske vlade od 1932. do 1934. godine.

69 KOLAR-DIMITRIJEVIĆ, „Socijalno-ekonomska politika gradske općine Zagreba”, 171244 (177).

70 Isto, 199. 
zakočio je sve njegove planove. Potrebne novce za javne radove nastojao je prikupiti i od Savske banovine, ali neuspješno. Od obećanih 4 milijuna dinara za održavanje nasipa od željezničkoga mosta do Trnja bilo je isplaćeno tek pola milijuna. ${ }^{71} \mathrm{U}$ svojem je mandatu, iako je prešutno bio prorežimski načelnik, Krbek prošao put od rane potpore Pribićevićevim samostalnim demokratima do približavanja krugu autonomaša, što ga je u konačnici i dovelo na mjesto podbana u Banovini Hrvatskoj. Udaljavanje od unitarističko jugoslavenskih opcija privelo ga je, čini se, i kraju mandata. Krbek je dao ostavku 1934., a naslijedio ga je tipični predstavnik bankarskoga kapitala, ravnatelj Gradske štedionice Rudolf Erber, član Jugoslavenske nacionalne stranke. Erberov mandat obilježilo je provjeravanje financijskoga rada dotadašnjih gradskih uprava, pri čemu su bile otkrivene i neke afere. Svakogodišnje poplave tjerale su ga i na stalna ulaganja u savski nasip.

Stjepan Srkulj u svojim je sjećanjima zapisao da je Vjekoslav Heinzel s načelničke dužnosti otišao s riječima: „Tak penez ga ni! Sad neka nek dela!”72 Zaista, financijsko stanje Grada nikada nije bilo potentno. Sve veće gradnje morale su se pokrivati iz zajmova, koje vrlo često nisu mogli dobiti ili htjeli ostvariti uslijed nepovoljnih uvjeta. Primjerice, u svojem drugom načelničkom mandatu (1928. - 1932.) Srkulj je neuspješno u inozemstvu nastojao ostvariti zajam od 100 milijuna dinara, a nakon deset mjeseci pregovora banka je, u vremenu diktature, odgovorila „da je novčano tržište za jedan vanjski zajam nepovoljno”. ${ }^{73}$ Zajam mu je bila spremna osigurati ,jedna druga američka skupina”, ali tek uz uvjet da dobiju 51 \% vlasničkoga udjela u Gradskoj električnoj centrali, što je odbijeno. Zajam je naposljetku podignut kod „sindikata zagrebačkih novčanih zavoda” uz kamatu 4 \% iznad „svakovremene kamate” Narodne banke na rok od četiri godine. ${ }^{74} \mathrm{~S}$ druge strane, gradnja kapitalnih objekata i uz kredite se odvijala sporo. Primjerice, odluku o izgradnji Gradske klaonice Gradsko je poglavarstvo donijelo u svibnju 1921., a klaonica je otvorena tek deset godina poslije, krajem rujna 1931. godine. ${ }^{75} \mathrm{U}$ međuvremenu se Grad tri puta pokušao kreditno zadužiti, od čega dva puta neuspješno, zbog čega je projekt i stajao. Prvi put 1922. Poglavarstvo se nastojalo zadužiti zajmom od 200 milijuna kruna, a drugi put 1928. u iznosu od 45 milijuna

\footnotetext{
Isto, 200.

SRKULJ, Memoari, 60.

Isto.

Isto.

Srkulj je u Memoarima (str. 58) naveo da je odluka o izgradnji nove gradske klaonice donesena u svibnju 1921., a u izvještajima Gradskoga poglavarstva vidljivo da je odluka o podizanju kredita za izgradnju donesena u svibnju 1922. godine. Usp. Zagreb godine 1913. - 1925., 2. dio, 23. O arhitekturi i projektu izgradnje nove klaonice vidi: BARIŠIĆ MARENIĆ, „Gradska klaonica i stočna tržnica u Zagrebu”, 370-383.
} 
dinara. ${ }^{76}$ Bio je ostvaren tek treći zajam od 40 milijuna dinara, od kojih je za klaonicu bilo odvojeno samo 10 milijuna, a u proračunu za 1930. uspjelo se isplanirati 20 milijuna, a za 1931. čak 42 milijuna dinara. ${ }^{77}$ Samo je arhitekt Walter Frese dva puta dobio honorar, za izradu prvoga projekta 1922. i njegovu doradu 1928. godine. ${ }^{78}$ Gradsko podizanje kredita znatno se smanjilo od 1931. i zbog utjecaja svjetske gospodarske krize, ali se i otplaćivanje onih starih otežalo, uslijed čega je Grad postao i insolventan. ${ }^{79}$

U uvjetima otežane stanogradnje i usporene transformacije grada javnost je burno reagirala na opremanje gradskih rezidencija ili njihovu gradnju. Veliki dio proračuna odlazio je na osobne izdatke gradskih službenika, kao i na fond za reprezentaciju gradskoga načelnika. ${ }^{80} \mathrm{Za}$ Srkuljeva načelništva Grad je za potrebe predstavljanja otkupio palaču obitelji Pongratz u Mesničkoj ulici, palaču Oršić-Rauch u Matoševoj br. 9, izgradio novi ljetnikovac na Rebru. ${ }^{81}$ Nasuprot tome, zadivljen čistoćom njemačkih gradova, posebice Dresdena, a ističući nemogućnost rješenja nečistoće u Zagrebu, Srkulj je tražio savjet od njemačkoga pročelnika građevnoga ureda. Kada mu je rekao da u Zagrebu ima jedva $30 \%$ asfaltiranih cesta, dresdenski mu je stručnjak odgovorio neka mu se javi kada taj iznos bude $96 \%{ }^{82}$ Takve političko-društvene odnose, kojima su ovi anegdotalni primjeri tek dijagnostički impulsi, pratilo je stalno optuživanje prošlih vlasti za svu sporost i nerješavanje problema, pa i onih s južnom periferijom. Heinzel je optuživao Srkulja za rastrošnost, Srkulj mu je vraćao primjerima njegove rastrošnosti i tereta prema tekućim proračunskim obvezama, a svi su opet isticali krivnju vlasti prije Prvoga svjetskog rata. ${ }^{83}$

\footnotetext{
76 Zajam od 500.000 britanskih funti s kamatom od $10 \%$ zagrebačko poglavarstvo prihvatilo je u svibnju 1922. uz zalog (osiguranje) gradskoga prihoda od najamnoga poreza, dohodaka onih gradskih poduzeća koja bi bila pokrenuta iz toga zajma, kao i svih gradskih nekretnina (Zagreb godine 1913. - 1925., 2. dio, 23). Zajam nije ostvaren zbog odugovlačenja konačnoga odobrenja britanske banke (KOLAR-DIMITRIJEVIĆ, Radni slojevi Zagreba od 1918. do 1931. godine, 122).

77 SRKULJ, Memoari, 58. Prvotno je 1927. Gradsko poglavarstvo za podmirenje troškova izgradnje Dolca i nove klaonice te reprogramiranje dotadašnjih kredita odobrilo podizanje velikoga kredita od 140 do 200 milijuna dinara. U konačnici je zbog niza poteškoća odobreno podizanje kredita od 40 milijuna dinara (KOLAR-DIMITRIJEVIĆ, Radni slojevi Zagreba od 1918. do 1931. godine, 122).

78 SRKULJ, Memoari, 56.

79 KOLAR-DIMITRIJEVIĆ, Radni slojevi Zagreba od 1918. do 1931. godine, 124.

80 Isto.

81 SRKULJ, Memoari, 58

82 Isto, 59.

83 Brojne su financijske afere pratile rad zagrebačkih gradskih poglavarstava. Primjerice, Vjekoslav Heinzel odstupio je s gradonačelničkoga mjesta zbog sve većega pritiska javnosti i oporbe zbog moguće korupcije u poslovima vezanim uz izgradnju Gradske klaonice. Čak su se i poslovi oko asfaltiranja ulica, koji su se zbog nekvalitetnoga asfalta iznova morali ponavljati, povezivali s korupcijom i povezanošću samo s jednom tvrtkom, onom Antuna Resa. Godine 1934. u reviziji poslovanja gradske blagajne otkriveni su golemi nedostaci, zbog čega je pokrenuta istraga protiv
} 
Tu pojavu može se pratiti i na primjeru rasprava o problematici bespravne gradnje na području Trnja. Na sjednicama Građevnoga regulatornog odbora 1929. brzo je iznjedren zaključak da je osnovni problem s bespravnom gradnjom nepostojanje generalne regulatorne osnove. Ivan Peršić isticao je da „ne leži krivnja na posle ratnim gradskim zastupstvima [...]. Kriva su tomu i gradska zastupstva prije rata” jer „poznato je, da se o regulaciji grada govori od god. 1900." ${ }^{44}$ Dugogodišnji gradonačelnik Heinzel pravdao je te 1929. godine i svoje načelnikovanje ističući da su ljudi „najradije gradili na nereguliranom tlu”, podsjećajući na odluke Gradskoga poglavarstva o parceliranju gradskoga zemljišta na Pongračevu i Kanalu. Za namjere odbora o zabrani daljnje bespravne gradnje naglasio je „da ne vjeruje, da će se puno moći učiniti” jer „ako mi danas zaključimo rušenje, već će sutra neka gospoda doći intervenirati i srušiti će svaku dobru akciju". ${ }^{85}$

Izričiti protivnik popuštanja zahtjevima predstavnika ilegalnih graditelja bio je zastupnik Nikola Hoffer, sa stavom da „ako ti mali ljudi, koji su prije više godina došli u Zagreb hoće da budu čestiti građani ovoga grada, ako od toga grada hoće da živu i da u njem nalaze svoje eksistencije, onda moraju biti svjesni toga da su dio čitave cjeline i da kao takovi imaju dužnost spram te cjeline inače izgleda, da su napravili grad u gradu i da su došli divlji, da tjeraju pitome" ${ }^{86}$ Takav se stav može primijetiti i unutar iste skupine - stanara južne periferije, samo onih koji su na to područje došli nešto prije. Stanovnici Paromlinske ceste, Sanske, Vrbaske i Plivske ulice žalili su se i molili podnačelnika Jakova Pavlinu, najvjerojatnije 1934., da se hitno spriječi daljnja bespravna gradnja ,jer se gradi i po danu i po noći”. U svojoj su molbi iznijeli da se na Paromlinskoj cesti između br. 41 i 45, kao i na Trnjanskom zavoju na praznom zemljištu događa parcelacija, „te iste parcele su iznajmili neki ljudi / kojima za sada još imena neznamo/ te natome mjestu počeli su graditi barake za stanovanje [...]. Ova svaka nastamba imati če zahod, smetište kao i druge nečisti, a bez kanalizacije. [...] Takovih nezdravih elemenata smo se s teškom mukom [...] riješili, onim danom kada smo dobili kanalizaciju" ${ }^{87}$ A upravo je protiv izgradnje komunalne infrastrukture u tim gradskim dijelovima bio Ivan Werner. On je na sjednici odbora 29. svibnja 1929. govorio protiv toga objašnjavajući da je periferija već djelomično dobila i ceste i javnu rasvjetu, a

voditelja Tržnoga odsjeka Dane Šarića i desetak činovnika, od kojih je jedan počinio samoubojstvo. Vidi: HUTINEC, GOLDSTEIN, Povijest grada Zagreba, knj. 2, 11, 26, 54.

84 HR-DAZG-10-14, Zapisnik sjednice građevno-regulatornog odbora od 31. svibnja 1929., $71 / 5$.

85 Isto.

86 Isto.

87 HR-DAZG-10-14, Zamolba stanovnika Paromlinske ceste, Sanske, Plivske i Vrbaske ulice da se obustavi privatna parcelacija i gradnja na Paromlinskoj cesti, 71/5. 
uskoro će dobiti i vodovod i kanalizaciju, a da nisu uložili ni novčić u modernizaciju, zaključujući: „To je valjda primila za nagradu što je tako izigravan zakon." 88

$\mathrm{Na}$ drugoj su strani vlasnici bespravnih gradnji okupljeni u udrugu Građanske komunalne organizacije malih kućeposjednika i periferije grada Zagreba jasno i oštro zahtijevali momentalnu izgradnju vodovoda, cesta i kanalizacije na južnoj periferiji, upozoravajući na krivnju i nebrigu Gradskoga poglavarstva, koje nije donijelo odgovarajuću regulatornu osnovu za taj dio grada. ${ }^{89}$ Nadalje, kao odgovor zahtjevima Gradskoga higijenskog odsjeka o stanju u kućama na periferiji, Udruga kućevlasnika žestoko je upozorila Poglavarstvo na njihove obveze i propuste. U svibnju 1929. pozvali su ih na hitno rješavanje otvorenih odvodnih kanala na periferiji „jer su leglo miliona štakora”, na hitno isušivanje močvara između Svetica i Kulmerovih livada, kao i na potrebu odstranjivanja skladišta sirovih koža na Trnjanskoj cesti. Također su poručili gradskom Higijenskom zavodu „da su stanovi u kućama na periferiji izgrađenima bez gradjevnih dozvola, daleko zdraviji nego li su to stanovi, za koje puka sirotinja plaća po 1000 do 1500 Din. mjesečno [...] u podrumima u kojima vlada užasan smrad od zahodskih cijevi, čitavih stovarišta djubra i raznih životinja, živadi i.t.d." ${ }^{90}$

Svojim zahtjevima Gradskom poglavarstvu organizirani građani zapravo su natjerali Grad da obrati pozornost na južnu periferiju, koju se više nije moglo ignorirati zbog njezine veličine i brojnosti. Posljedično, pitanje periferije postalo je i snažno političko pitanje, posebice lijeve političke provenijencije. Iz takva miljea bio je pokrenut i spomenuti list Glas Trešnjevke / Glas Periferije, koji se pretežno bavio osvještavanjem komunalnih problema i teškoća stanovništva toga prostora, osnažujući im glas i položaj. List nije izlazio ni godinu dana (1932./33.), a bio je ukinut zbog cenzure. S druge strane političkoga spektra bilo je razmišljanja i zagovaranja da bi trebalo zabraniti i takve udruge stanovnika periferije. Arhitekt Aleksandar Freudenreich, jedan od članova Građevnoga odbora, gledao je na pojavu divlje gradnje kao na socijalni proces koji se nije mogao tolerirati, ali se mogao ispraviti. Budući da je kao dio prve generacije Iblerove Škole arhitekture na Akademiji likovnih umjetnosti bio blizak i djelovanju udruženja umjetnika „Zemlja“ kojemu nije pripadao, ali je poznavao njihove ideje i djelovanje, naglašavao je i socijalnu osviještenost rješavanja ovog problema. U naseljavanju periferije vidio je uzorak prema

88 HR-DAZG-10-14, Zapisnik sjednice građevno-regulatornog odbora od 31. svibnja 1929., $71 / 5$.

89 HR-DAZG-10-14, Zamolba Gradske komunalne organizacije malih kućeposjednika periferije grada Zagreba gradskom zastupstvu od 5. svibnja 1929., 71/5.

90 Isto. 
kojem „mali čovjek” dođe iz provincije prodavši „gdjekoji svoju kućicu, gotovo svaki svoj 'grunt' i za 4 mjeseca postaje u Zagrebu kućevlasnik “ističući da gradsko građevno redarstvo mora ponajviše utjecati na popravak tih kuća kojima bi se potom podijelile i građevinske dozvole. ${ }^{91}$

Gradsko poglavarstvo opravdavalo je kašnjenje s regulatornom osnovom navodeći pet razloga: neriješeno pitanje savske luke, kanala na Savi, regulacije Save, novoga željezničkog mosta te potencijalno izmještanje željezničke pruge i kolodvora. ${ }^{92}$ Poglavarstvo je na Savu gledalo kao na trgovačko-prometnu vrijednost i zagovaralo je razvitak grada prema rijeci, a u tom smislu deklarativno je 1929. pozvalo državne „čimbenike” da što prije donesu potrebna rješenja za regulaciju Save i željeznički promet.

Do srpnja 1929. u Zagrebu je bilo podignuto oko 4000 bespravnih objekata, najvećim dijelom na južnoj periferiji. Uslijed upozorenja Gradskoga higijenskog odsjeka, ali i samih vlasnika tih građevina, Gradsko je zastupstvo, uz podjelu naknadnih građevinskih dozvola, u konačnici odlučilo zabraniti daljnju izgradnju bez građevinske dozvole pod prijetnjom rušenja objekata. Ta je odluka postala službena i pravno vrijedna 3. kolovoza 1929. godine. ${ }^{93}$ Prema podacima Gradskoga građevnog odsjeka, nakon toga datuma stanje s ilegalnom gradnjom bitno se popravilo i ona se ozbiljno smanjila. Tijekom ostatka 1929. i 1930. gradsko načelstvo reagiralo je tek u nekoliko slučajeva rušenjem objekata. Međutim, kroničan problem nedostatka stanova, i još važnije urbanističkoga plana, nastavio se i ponovno uzrokovao „divlju gradnju” 1931. i 1932., kada je izgrađeno oko 250 novih bespravnih objekata. Gradsko načelstvo, uz rušenje 22 kuće, pribjeglo je i snažnoj kampanji protiv te pojave javnim oglasima i onima u tisku, kao i usmenim upozorenjima, ali bez učinka. ${ }^{94}$ Reakcija je bila upravo onakva kakvu je predvidio bivši načelnik Heinzel, da „ako mi danas zaključimo rušenje, već će sutra neka gospoda doći intervenirati" ${ }^{95}$

Spomenute udruge građana koje su uspješno utjecale na donošenje odluke o naknadnoj dodjeli građevinskih dozvola nastavile su i osnažile svoje djelovanje, proširile članstvo, utjecaj i kampanju. Tako je Komunalno-ekonomska organizacija za južnu periferiju prijavila postupke Gradskoga poglavarstva Ministarstvu unutarnjih poslova, koje je zatražilo izvješće od Banske upra-

91 HR-DAZG-10-14, Zapisnik sjednice građevno-regulatornog odbora od 26. travnja 1929., $71 / 5$.

92 HR-DAZG-10-14, Prijedlog građevno-regulatornog odbora gradskom poglavarstvu, Broj: 32818-XIIA-1929., 71/5.

93 HR-DAZG-10-14, Izvještaj o nedozvoljenoj građevnoj djelatnosti, s. n., 71/5.

94 Isto.

95 HR-DAZG-10-14, Zapisnik sjednice građevno-regulatornog odbora od 31. svibnja 1929., $71 / 5$. 
ve Savske banovine, koja je odmah obustavila sva daljnja rušenja do izrade potpunoga izvješća. ${ }^{96} \mathrm{Za}$ tu se odluku vrlo brzo saznalo u javnosti i došlo je do trenutačne eksplozije „divlje gradnje”. U roku od samo četrnaest dana izgrađeno je na južnoj periferiji čak 70 objekata. ${ }^{97}$ Gradsko načelstvo naredilo je njihovo uklanjanje, ali kako se nije moglo djelovati zbog još uvijek otvorene istrage Savske banovine i prevelikoga broja novih objekata, ono više nije imalo tehničkih ni financijskih mogućnosti djelovati. Načelstvo je pribjeglo novoj taktici u utrci s bespravnim graditeljima: uputilo je molbu Upravi policije u Zagrebu da svaki dan upućuje ophodnje južno od željezničke pruge, a posebice na područje Trnja, Volovčice, Ravnica, Martinovke, Livadarskoga puta, Njivica i potoka Črnomerca. Zadatak im je bio rastjerati radnike na podizanju tih objekata, a onda da „makar i telefonski obavijesti Gradsko poglavarstvo” za daljnje djelovanje. ${ }^{98}$ Iako je takva akcija imala učinka, on je trajao samo dok je policija bila na terenu. Potpuni nedostatak autoriteta vlasti uzrokovao je da su „interesanti nastavili [s] građenjem po danu i po noći te blagdanima, samo da postave krov", a rušenju se nije moglo pristupiti jer bi do donošenja odluke o rušenju objekti već bili najvećim dijelom dovršeni i, najvažnije, nastanjeni. ${ }^{99}$

Iako je Gradsko poglavarstvo i rušilo bespravno sagrađene kuće i zabranjivalo njihovu gradnju, Građevni regulatorni odbor, a u konačnici i Gradsko zastupstvo 1929., za vrijeme načelnika Srkulja, donijeli su odluku o legaliziranju svih kuća na tom području. Ta je odluka imala nekoliko faza razvoja. Isprva je Gradsko zastupstvo izglasalo odluku o privremenom izdavanju građevinskih dozvola do 1948., ali samo na području Trnja, odnosno između željezničke pruge, Save, Savske ceste i potoka Medveščaka, te zabranilo svu gradnju na pet godina. ${ }^{100}$ Iste je godine ta odluka dopunjena zaključkom da se naknadne građevinske dozvole odnose na sve bespravne gradnje u gradu. Prateći te odluke, donesen je i popratni pravilnik, Propisnik o izuzetnim građevnim olakšicama od postojećeg građevnog reda za grad Zagreb, s olakšanim uvjetima za izgradnju manjih kuća da bi se što više uredila neregulirana izgradnja. Naposljetku, iste su godine ukinute sve prijašnje odredbe o privremenim građevinskim

\footnotetext{
96 HR-DAZG-10-14, Izvještaj o nedozvoljenoj građevnoj djelatnosti, s. n., 71/5. Komunalno-ekonomsko udruženje u svojoj predstavci zatražilo je od Ministarstva unutarnjih poslova da se obustavi rušenje samo osamdesetak bespravnih kuća podignutih do 31. srpnja 1931., čemu je Kraljevska banska uprava Savske banovine u Zagrebu i udovoljila. Poslije je došlo do sukoba Savske banovine i Gradskoga poglavarstva, koje je tu odluku protumačilo kao konačnu obustavu rušenja svih bespravnih objekata prije i nakon odluke. Vidi: HR-DAZG-10-14, Kraljevska banska uprava Savske banovine gradskom načelstvu Zagreba od 17. kolovoza 1932., 71/5.

97 HR-DAZG-10-14, Izvještaj o nedozvoljenoj građevnoj djelatnosti, s. n., 71/5.

98 Isto.

99 Isto.

100 HR-DAZG-10-14, Građenje kuća bez dozvole i kuća na tuđem zemljištu, Broj: 1713-IIIInt-1941., kt. 71/5.
} 
dozvolama da bi se odlučilo da se konačne građevinske dozvole izdaju svim vlasnicima kuća koje su ispunjavale sve uvjete novoga Propisnika s olakšicama, a privremene građevinske dozvole (do 1948.) onim kućama čija gradnja ispunjava najnužnije tehničko-higijenske uvjete novoga pravilnika. ${ }^{101}$

Takav razvoj situacije bio je oblikovan željom gradskih vlasti za izbjegavanjem socijalnih nemira, ali i snažnim utjecajem stanovnika periferije koji su se udruživali u udruge građana, čiji je broj do 1932. narastao na 33 organizacije. Iako je bilo kraćih izleta sličnih udruženja (Stanarinski blok) u smislu sudjelovanja na izborima, te su organizacije imale drukčiju taktiku. Kao njihov opunomoćenik u Gradskom zastupstvu nastupao je primjerice i gradski podnačelnik u mandatu Ive Krbeka Jakob Pavlina. On nikako nije pripadao političarima lijeve orijentacije, bio je i član prorežimske Jugoslavenske radikalno seljačke demokracije. Pavlina je zagovarao njihove interese boreći se da naknadne građevinske dozvole dobiju svi građani, što se u konačnici poklapalo s Krbekovim namjerama. Prvenstveno je Pavlina prosvjedovao protiv korištenja naziva „divlja gradnja” jer „u njima ne stanuju divljaci, nego dobri i plemeniti građani [...] [koji] ne traže ništa, niti su od svoga grada išta tražili, nego su si sami otkidajući od usta svoje i onako oskudne zalogaje sagradili krov nad glavom". ${ }^{102}$

Dakako, i u 30-ima je bilo protivnika takve politike gradske uprave. Jedan od istaknutijih bio je ing. Dragutin Vajda, načelnik Gradskoga građevnog odsjeka u mandatu Vjekoslava Heinzela. On se na sjednici Gradskoga regulacionog odbora 1932. usprotivio Pavlini: „Periferija živi svojim životom. I svaki čovjek ima pravo tražiti da mu se i na periferiji omogući pristojan način života, ali nitko nema pravo tražiti, da periferija bude uređena isto tako kao centrum grada. [...] Treba znati, da troškovi za cestu, vodovod i kanalizaciju zajedno sa zemljištem premašuju vrijednost izgrađenih kuća na periferiji [...] Kuća malog čovjeka na periferiji je provizorium, koji će s vremenom nestati." ${ }^{103} \mathrm{Bez}$ obzira na političku orijentaciju gradskih poglavarstava ili zastupstava, na južnoj periferiji bespravna gradnja nije prestajala, nego je u godišnjem prosjeku iznosila između 100 i 150 novih objekata. Do donošenja i konačnoga odobrenja regulatorne osnove 1940. Poglavarstvu je tek ostalo voditi evidenciju o takvim građevinama.

Kronični manjak novca za veće javne radove na uređenju savskoga nasipa ili komunalne infrastrukture južne periferije i sporost u donošenju generalnoga urbanističkog plana bile su karakteristike zagrebačkoga međuraća. Primje-

101 Isto.

102 HR-DAZG-10, Predsjedništvo, Zapisnici Građevno-regulatornog odbora, PRS 279, Sjednica od 14. listopada 1932.

103 Isto. 
rice, izgradnju podvožnjaka u Miramarskoj čekalo se dvadeset godina, njegovo asfaltiranje sljedećih trinaest godina, a gotovo potpunu izgradnju trnjanskoga nasipa tridesetak godina. U konačnici, uklanjanje glavnoga problema bespravne izgradnje južne periferije, odnosno odobrenje Glavne regulatorne osnove, uredbe o njezinu izvođenju i Građevinskoga pravilnika, formalno se dogodilo tek 1940., za vrijeme Banovine Hrvatske i povjerenika gradske općine Zagreba, bivšega suca Okružnoga suda u Zagrebu, Mate Starčevića. ${ }^{104}$

Uslijed isprepletene državno-gradske administrativne sporosti i gotovo četrdesetogodišnjega nedonošenja urbanističkoga plana, Gradsko poglavarstvo okrenulo se dijelovima grada (na zapadu i još više na istoku) gdje su se regulirano gradili stanovi ili infrastruktura. Dolazak, a onda i ostanak doseljenika na južnoj periferiji primorao je Gradsko poglavarstvo da se tim prostorom ipak počne baviti u smislu rezidencijalnoga dijela, a ne tek industrijskoga i rekreativnoga. Međutim, pravilno i sveobuhvatno rješavanje problema periferije značilo bi i vrlo visoka ulaganja, za koja nije bilo mogućnosti. U gospodarsko-političkim i poslovnim uvjetima upravljanja Gradskim poglavarstvom široko rješenje problema periferije nije bilo moguće.

\section{Zaključak}

Prostor južne periferije pojavio se u urbanističkim planiranjima Gradskoga poglavarstva još krajem XIX. stoljeća, pretežno kao prostor za savsku luku te industrijskoga i rekreativnoga karaktera. Rezidencijalnu vrijednost toga prostora predvidio je tek Glavni regulatorni plan iz 1936., odobren 1940. godine. Nedostatak regulatornih osnova za to područje bio je uzrokovan nereguliranim tokom Save, koja je još uvijek prijetila godišnjim poplavama, ali i omeđenošću željezničkom prugom sa sjeverne strane, koja je onemogućila komunikaciju s gradskim Donjim gradom i središtem. To „željezničko pitanje” opterećivalo je Gradsko poglavarstvo desetljećima nakon izgradnje zgrade Glavnoga kolodvora 1892., a ponešto je ublaženo tek 1913. izgradnjom podvožnjaka na Miramarskoj cesti. Odvojenost južne periferije od grada željezničkom prugom i neregulirana Sava onemogućile su razvoj grada u pravcu sjever-jug te se on razvijao longitudinalno. Reguliranje Save otpočelo je 1899. i do 1918. rijeku se uspjelo staviti u jedno korito, odcijepivši joj rukavce, te položiti u karakterističan luk sa središnjom osi okomitom na srednjovjekovno gradsko središte. Međutim, opasnost od poplava nastavila se sve do 30-ih go-

104 HR-DAZG-10-14, Oglas: Građenje bez dozvole, Broj: 106-XVI-1940., 71/5. Važnost toga događaja bila je toliko osviještena da ju je gradski načelnik naglasio u tekstu Oglasa: „U povodu ovog važnog datuma u životu našega grada mora se naglasiti dužnost svakog građanina da poštuje i čuva zakone izgradnje grada, jer nas oni vode uređenju zdravog i korisnog obitavanja u velikoj zajednici grada." 
dina, kada je dovršen trnjanski nasip i time barem minimalno zaštićena južna granica južne periferije.

Snažan rast stanovništva u gradovima nakon Prvoga svjetskog rata bio je globalna karakteristika koja se dogodila i Zagrebu. Radilo se većinom o doseljenicima iz zagrebačke ruralne okolice i sjeverne Hrvatske. Jedan od prvih problema koji su se odmah otkrili bio je nedostatak stanova, posebice onih koje su si ti doseljenici mogli priuštiti. Iako su mnogi od njih imali zaposlenje u gradu ili u tvornicama koje su se dotad već razvile na periferiji, ograničena i skromna primanja ubrzo su ih istjerala iz gradskoga središta prema periferiji. Tu su, u najvećem broju na iznajmljenim zemljištima, podizali kuće te imali prostor i za uzgoj vrtova i domaćih životinja. Najizraženija karakteristika stanovnika južne periferije bila je bespravna gradnja, a u međuraću je moglo biti podignuto od 5000 do 6000 takvih građevina. Ta pojava nužno je nove sugrađane dovela $u$ antipodni položaj prema Gradskom poglavarstvu.

Marksistička historiografija optužila je "građansku vlast” da je stanovnike periferije namjerno ignorirala. No takva se ocjena čini pretjeranom, iako su se građanima periferije često obraćali kao „malim ljudima”. Različita gradska poglavarstva, posebice u 30-ima, imala su izraženi socijalni smjer, ponajviše u osnovnim socijalnim naknadama, ali i gradnji ipak ograničena broja stanova za siromašniji sloj stanovništva. Čini se vjerojatnijim da su gradske vlasti ignorirale prostor južne periferije. Gradsko poglavarstvo nije imalo dovoljno financijskih sredstava da se nosi s uređenjem nesavršenoga zemljišta koje je željeznicom doslovno bilo odvojeno od grada, a dodatno i izloženo poplavama, što je u konačnici samo još više pojačavalo međusobni osjećaj izdvojenosti.

U čitavom razdoblju stanovnike periferije oslovljavalo se kao „male ljude” i nikada nisu dosegnuli razinu „građana”, označavajući taj prostor svojevrsnim „ne-gradom”. U tom smislu ne čudi ni da je nakon poplave 1923. samo 75 Zagrepčana doniralo (većinom neuporabljivu) odjeću i obuću za nastradale sugrađane s periferije. Njihov je odnos bio problematičan i međusobno optužujući. Međutim, ti su „ne-građani” i „mali ljudi” zapravo natjerali Gradsko poglavarstvo da se počne baviti južnom periferijom. Pozitivni pomaci mogu se primijetiti tek od 30-ih godina i mandata Ive Krbeka. Nakon nagloga naseljavanja iza Prvoga svjetskog rata do 1928. stanari južne periferije dosegnuli su kritičnu masu, odnosno brojnost koja im je omogućila ostanak na tom području. Idealan plan Gradskoga poglavarstva bio je da se bespravnim graditeljima ili otkupi kuća ili ponudi zemljište u reguliranom dijelu grada i da se tako taj prostor oslobodi za neko buduće urbanističko uređenje. Međutim, kroničan nedostatak financijskih sredstava, nedovoljno gradskoga zemljišta i neizgradnja komunalne infrastrukture osujetili su ta nastojanja i produbili razlike između "grada” i „periferije”. 


\section{Izvori}

HR-DAZG-10: Hrvatska, Državni arhiv u Zagrebu, fond 10, Gradsko poglavarstvo Zagreb.

\section{Literatura}

ANDRIJEVIĆ, Svebor; BAŠIĆ, Silvio; TUTEK, Ivana. „Željeznica u prostornim planovima grada Zagreba”. Prostor 13 (2005), br. 2 (30): 175-186.

BARIŠIĆ MARENIĆ, Zrinka. „Gradska klaonica i stočna tržnica u Zagrebu arhitekta Waltera Fresea”. Prostor 23 (2015), br. 2 (50): 370-383.

BARIŠIĆ MARENIĆ, Zrinka; ŠTULHOFER, Ariana; UCHYTIL, Andrej. „Zgrada ženske realne gimnazije sestara milosrdnica u Zagrebu arhitekta Zvonimira Vrkljana (1937.-1939.)”. Prostor 17 (2009), br. 2 (38): 284-297.

ČAVLOVIĆ, Melita; LOVRENČIĆ, Lana; SEVŠEK, Antun. „Dvije 'polovice' Novog Zagreba”. U: Mapping urban changes, ur. Ana Plosnić Škarić. Zagreb: Institut za povijest umjetnosti, 2017, 456-489

ČENGIĆ, Dubravka. Gradsko poglavarstvo Zagreb 1850. - 1945. Zagreb: Državni arhiv u Zagrebu, 2013.

ČEPO, Zlatko. „O dva prethodna rada i o nekim problemima izrade povijesti komunističkog pokreta u Zagrebu”. Časopis za suvremenu povijest 15 (1983), br. 3: 45-48.

GAŠPAROVIĆ, Ana; SOPINA, Sanja. „Uloga pejsaža u planiranju grada Zagreba od početka 20. stoljeća do početka 21. stoljeća”. Prostor 26 (2018), br. 1 (55): 132-145.

Godišnjak banske vlasti Banovine Hrvatske 1939 - 20. VIII - 1940. Zagreb: Tisak Zaklade Narodnih novina u Zagrebu, 1940.

HUTINEC, Goran; GOLDSTEIN, Ivo. Povijest grada Zagreba, knj. 2: 20. i 21. stoljeće. Zagreb: Novi Liber, 2013.

JURIĆ, Zlatko. „Građevni redovi i regulatorno planiranje Zagreba u razdoblju od 1850. do 1894. godine”. U: Moderno lice grada, ur. Marino Manin i Lidija Bencetić. Zagreb: Hrvatski institut za povijest, 2019, 19-48.

KAHLE, Darko. „Građevinski propisi za grad Zagreb u razdoblju od 1919. do 1931. godine i Građevinski zakon iz 1931. godine”. Prostor 14 (2006), br. 1 (31): 116-129.

KNEŽEVIĆ, Snješka. „Regulatorna osnova Milana Lenucija za dio Zagreba od željezničke pruge do rijeke Save iz 1907.” Radovi Instituta za povijest umjetnosti 16 (1992): 169-197. 
KOLAR-DIMITRIJEVIĆ, Mira. Radni slojevi Zagreba od 1918. do 1931. godine. Zagreb: Institut za historiju radničkog pokreta Hrvatske, 1973.

KOLAR-DIMITRIJEVIĆ, Mira. „Socijalni slojevi i uvjeti života u južnom dijelu Zagreba u međuratnom razdoblju (1918.-1941.)”. Hrvatske vode 18 (2010), br. 73: 221-230.

KOLAR-DIMITRIJEVIĆ, Mira. „Socijalno-ekonomska politika gradske općine Zagreba s obzirom na položaj radničkog stanovništva od velike svjetske krize do početka Drugoga svjetskoga rata (1931-1939)". Povijesni prilozi 2 (1983), br. 1: 171-244.

KOLAR-DIMITRIJEVIĆ, Mira. „Stanovništvo Trnja do 1941. godine”. U: Zagrebačka općina Trnje u radničkom i komunističkom pokretu i socijalističkoj revoluciji, ur. Mira Kolar-Dimitrijević. Zagreb: Skupština općine Trnje, 1981, 27-32.

Mali statistički priručnik grada Zagreba 1931. Zagreb: Gradsko načelstvo u Zagrebu, s. a.

MATKOVIĆ, Irena; OBAD ŠĆITAROCI, Mladen. „Rijeka Sava s priobaljem u Zagrebu. Prijedlozi za uređivanje obala Save 1899. - 2010.” Prostor 20 (2012), br. 1 (43): 46-59.

MATKOVIĆ, Stjepan. „Uređenje rijeke Save na području oko Zagreba s posebnim osvrtom na zahvate u doba Austro-Ugarske”. U: Zbornik Mire Kolar-Dimitrijević. Zbornik radova povodom 70. rođendana, ur. Damir Agičić. Zagreb: FF Press, 2003, 219-230.

OŠTRIĆ, Vlado. „Urbanizacija Trnja”. U: Zagrebačka općina Trnje u radničkom i komunističkom pokretu i socijalističkoj revoluciji, ur. Mira Kolar-Dimitrijević. Zagreb: Skupština općine Trnje, 1981, 17-26.

RADONIĆ VRANJKOVIĆ, Paulina. „Gradski i parlamentarni izbori u Zagrebu”. Radovi Zavoda za hrvatsku povijest 40 (2008): 249-274.

RADOVIĆ MAHEČIĆ, Darja. „Socijalno stanovanje međuratnog Zagreba”. Radovi Instituta za povijest umjetnosti 17 (1993), br. 2: 141-155.

RADOVIĆ MAHEČIĆ, Darja. Socijalno stanovanje međuratnog Zagreba = Social housing in Zagreb between the wars. Zagreb: Horetzky, 2002.

SLUKAN ALTIĆ, Mirela. „Povijest regulacije rijeke Save kod Zagreba i njezine posljedice na izgradnju grada”. Hrvatske vode 18 (2010), br. 73: 205-212.

SOKOL GOJNIK, Zorana; GOJNIK, Igor. „Crkva Krista Kralja u Zagrebu Ivana Meštrovića. Arhitektonski projekti”. Prostor 18 (2010), br. 2 (40): 306321.

SOKOLIĆ, Nevenka; JUKIĆ, Tihomir. „Zagrebačko naselje Stara Peščenica”. Prostor 18 (2010), br. 2 (40): 288-305. 
SRKULJ, Stjepan. Memoari (Zagreb, 1963), prir. Tomislav Jonjić, Stjepan Matković i Zlatko Matijević. U: Pilar: časopis za društvene i humanističke studije VII (2012), br. 14 (2): 5-89.

ŠMIT, Krunoslav; GAŠPAROVIĆ, Sanja; PETROVIĆ KRAJNIK, Lea; MLINAR, Ivan; KRAJNIK, Damir. Prostorno planska dokumentacija Zagreba i zagrebačkog područja 20. stoljeća i početka 21. stoljeća. Čimbenici koji su utjecali na provedbu planova od 1986. godine. Zagreb: Arhitektonski fakultet, 2019.

ŠTULHOFER, Ariana. „Prilog istraživanju povijesti izgradnje športskorekreacijskih objekata u Zagrebu. Kronologija izgradnje od 1808. do 1975. godine”. Prostor 3 (1995), br. 1 (9): 55-72.

TIMET, Tomislav. Stambena izgradnja Zagreba do 1954. godine. Ekonomsko-historijska analiza. Zagreb: JAZU, 1961.

TOMAŠEGOVIĆ, Nikola. „Polemika o željezničkom pitanju do 1862. godine u Pozoru i Narodnim novinama”. Povijest u nastavi 12 (2014), br. 23 (1): 35-54.

Vijenac (Zagreb), 2000.

VUKSANOVIĆ-MACURA, Zlata. Život na ivici. Stanovanje sirotinje u Beogradu 1919-1941. Beograd: Orion art, 2012.

Zagreb godine 1913. - 1925. Izvještaji Gradskog poglavarstva u Zagrebu. Zagreb: Državni arhiv u Zagrebu, 2015.

Župa Krista Kralja. Zagreb - Trnje. Povijest župe. Pristup ostvaren 3. 11. 2019. https://zupakristakraljatrnje.hr/iz-povijesti/povijest-zupe/. 


\section{SUMMARY}

\section{The Relationship of the Zagreb City Authorities towards the Southern Periphery in the Interwar Period}

The southern periphery area appeared in the city government's development plans in the late $19^{\text {th }}$ century, and was envisioned as an industrial and recreative area that would include a port on the river Sava. Its value as a residential area was foreseen only in the Main Regulatory Plan of 1930/31, which was approved in 1940. The lack of a regulatory basis for this area was the consequence of the unregulated flow of the Sava, whose annual flooding remained a threat, and also of the railway to the north, which cut the area off from the Lower Town and city centre. This so-called 'Railway Question' burdened the city government for decades after the erection of the Main Railway Station building in 1892, though it was somewhat ameliorated by the construction of an underpass on Miramarska Road in 1913. The separation of the southern periphery from the city due to the railway and the unregulated Sava prevented the development of the city in the north-south direction, so it developed longitudinally. The regulation of the Sava began in 1899, and by 1918 the river was consolidated into a single riverbed, its branches were cut off, and it was set into a characteristic bend with a centreline perpendicular to the medieval city core. However, the threat of flooding continued until the 1930s, when the Trnje embankment was completed, providing at least some protection for the southern border of the southern periphery.

An urban population boom, characteristic of cities across the globe after World War I, took place in Zagreb. Most of the growth was due to people moving in from Zagreb's rural surroundings and northern Croatia. One of the first problems that were detected was the lack of housing, especially that which would be affordable to the newly arrived immigrants. Although many of them found employment in the city or the factories that had by then developed on its periphery, their limited and modest incomes soon drove them out of the city centre and towards the periphery. There they built houses and had space for gardens and domestic animals, mostly on rented lots. The most pronounced characteristic of the population of the southern periphery was illegal construction; between 5,000 and 6,000 such buildings were erected in the interwar period. This phenomenon naturally led the new citizens into conflict with the city government.

Even though Marxist historiography accused the 'bourgeois government' of deliberately ignoring the population of the periphery, this seems to be an 
exaggerated interpretation, though these citizens were often treated as 'little people'. Various city governments, especially in the 1930s, had a pronounced social dimension, especially in regard to basic social benefits, but also in the construction of a limited number of dwellings for the poorer strata of the population. It seems more accurate to say that the city authorities ignored the southern periphery area. The city government lacked the funds to properly deal with the less-than-ideal area that was literally cut off from the city due to the railway and also exposed to flooding, which reinforced the mutual feeling of isolation.

In this entire period, the population of the southern periphery was addressed as 'little people' and they never reached the level of 'citizens', marking this area a sort of 'non-city'. In this sense, it is no wonder that, after the flood of 1923, only around 75 Zagreb citizens donated (mostly useless) clothing and footwear to victims from the periphery. Their relationship was problematic and full of mutual accusations. However, these 'non-citizens' and 'little people' actually forced the city government to begin addressing the southern periphery. Positive changes can be detected from the 1930s, during the mandate of Ivo Krbek. Following the mass immigration after World War I and until 1928, the inhabitants of the southern periphery reached a critical mass, i.e. they had sufficient numbers to allow them to remain in this area. The ideal plan of the city government was to buy houses from illegal builders or to offer them land in the regulated parts of the city, and thus free up this space for some future urban development. However, the chronic lack of funds and lots as well as the inadequate utility infrastructure hindered these efforts and widened the gap between 'city' and 'periphery'.

Key words: Zagreb; southern periphery; 1918-1941; regulation of the river Sava; illegal building 